\title{
ICRU 報 告-1980年
}

\author{
癌研究会附属病院 放射線科
}

津 屋, 坦

1980年度 ICRU 会議は 7 月21 28日亿亘り, Finland

の Helsinki 飞於いて開獕され，主として次の 4 つの議 題が討議された。

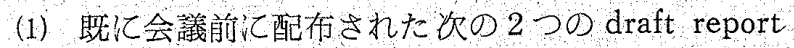
《ついての review が行わ机，細部に再検討の余地があ るととが指摘されたか，原則的とは出版することが承認 された。

- Radiation Dosimetry: Electron Beams with Energies between 1 and $50 \mathrm{MeV}$

- The Dosimetry of Pulsed Radiation

（2）委員会に於いて既に採用が決定されている下記課 題について, subgroup の報告畫作成進行状沅が報告, 検討され，之の中の $2 \sim 3$ については1981年度の会議に draft report が提出される予定である.

- $\mathrm{C}_{\lambda}$ and $\mathrm{C}_{\mathrm{E}}$

- Clinical dosimetry for neutrons

- Computer uses in radiotherapy

- Definitions and terminology for computed tomography

- Determination of absorbed dose distribution around a source used for interstitial therapy

- Dose specification for reporting intracavitary and interstitial therapy

- Measurement of low-level radioactivity in humans

- Microdosimetry

- Modulation transfer function for screen-film systems

- Photographic dosimetry in external beam therapy

- Practical determination of dose equivalent index

- Scanning - Stopping power

又前年度の会議以後出版されたものは, ICRU Report 32,33の2つであるが次にその概容を紹介する.

(a) ICRU Report 32, Methods of Assessment Dose in Clinical Use of Radionuclides
とれは MIRD 報告 (Medical Internal Dose Committee of the Society of Nuclear Medicine, U.S.A., 19681970) のICRU 版とも称すべきものであるが, 主として 診断用放射線医楽品投与後の関心組織又は 器管 (target region) に打ける吸収線量を計算するための基本公式と， それに必要な物理データ，生物データ，㢌用限界，精度 等の問題点を緾めたもので, 数例の計算の具体例が挙げ られているが，今後更に種々の放射性医薬品投与の吸收， 分布，代謝，排泄，データの集積が必要であることが強 調されている.

(b) ICRU Report 33, Radiation Quantities and Units

これは ICRU Report 11(1967)度ひ 19(1973)禹者を統 合した改訂版と言うべきものであって，SI 単位への統 合と，新しい特別の単位の導入を期とした久し振りの大 改訂である。因みに Gy 及の Bq (1975年第15回度量衡総 会にて決定) 汉び線量当量の Sv (1979年第16回度量衡総 会にて決定) への, 従来の $\mathrm{rad}, \mathrm{Ci}, \mathrm{rem}$ 加の切換えの 期限は1985年と決定されている. 既刊の Report と比較 して, Radiometry に新しい量として, particle number radiant energy, (particle) flux, energy flux, particle radiance, energy radiance が追加され, 相互作用の中に radiation chemical yield $\not$, 又放射能に air kerma-rate constant が追加されている，別项の線量当量では従来の 3つの量の夫タの線量率 (rate), shallow 及び deep dose equivalent index 等が追加され，従来の報告に対す る種々の問題点, 疑問点を明らか沉するよう改訂, 増補 されて居り，今後の指針を示したものである。

(3) 今後の報告書の課題しして次の5者が採用され， 新しいReport Committee が発足した. 又 “The effect of radiation on materials" 及 $ひ$ "tissue equivalence" の2つのテーマは新しい筫の放射線治潦，彰断に対応す るものとして重要と考えられるが, 今回は pending とな 
った.

- Absolute and Ralative Dosimitry at Hith Doses

- Chemical Dosimetry

- Quality Assurance of Diagnostic Radiology Equipment

- Quality Assurance of External Beam Therapy Equipment

-Specification and Quality Assurance of Scintillation Cameras

（4）次回 ICRU 会議の開慛地，日時につけては，第16 回国際放射線学会 (ICR) 之同時に, ベルギーの Brussels 市と決定し，その際 Gray Medal Lecture 乙同時に, ICR との合同シンポシウムが企画されたが，そのテーマ と演者は次の通りである。

Overview of ICRU Activities-Harold O. Wyckoff

The Definition of Radiation Quality-Harald H. Rossi

Combination Therapy: Radiobiology or Clinical Medicine?-Warren K. Sinclair

Problems in Reporting Theraputic Irradiation-Andre Wambersie
その他, CIE 又は CIP などの他の団体に执てて, 非電 離性放射線に使用されている量のうち共通なすの及びそ の単位の名称の統一性の問題, 国際的なSecondary Standards Dosimetry Laboratory $の$ network の現状等種々 の報告があり，合後息接な関係を保ってゆくことか確 認された。

\section{文 献}

1) Yamaguchi, H., et al.: The transformation method for the MIRD absorbed fraction as applied to various physiques. Phys. Med. Biol,, 20, 593-601 (1975).

2) Yamaguchi, H.: Estimation of internal radiation dose for various phyisiques using MIRD adult absorbed fractions. Acta Radiologica Oncology, 17, 429-439, (1978).

3）山口：寛：大きさの異なる人体へMIRD 法を適用 する際の変換法. 日医放会誌, 39, 252-266, (1979).

4) ICRUレポート32,33. 日本医放会誌，40，1116-1117 (雑録), (1980). 